Article

\title{
Social Considerations of Large River Sanctuaries: A Case Study from the Hilsa Shad Fishery in Bangladesh
}

\author{
Mohammad Mahmudul Islam 1,*(D), Rumana Aktar 2 (1), Md. Nahiduzzaman 2, \\ Benoy Kumar Barman ${ }^{2}$ and Md. Abdul Wahab ${ }^{2}$ \\ 1 Department of Coastal and Marine Fisheries, Sylhet Agricultural University, Sylhet 3100, Bangladesh \\ 2 WorldFish, Bangladesh and South Asia Office, House\# 22B, Road\# 07, Block-F, Banani, \\ Dhaka 1213, Bangladesh; R.Akter@cgiar.org (R.A); N.Md@cgiar.org (M.N.); \\ B.Barman@cgiar.org (B.K.B.); A.Wahab@cgiar.org (M.A.W.) \\ * Correspondence: mahmud.cmf@sau.ac.bd; Tel.: +88-0821-761952
}

Received: 6 February 2018; Accepted: 10 April 2018; Published: 19 April 2018

\begin{abstract}
The establishment of a sanctuary is often suggested as an effective strategy for ecological restoration, though social aspects of such attempts are often overlooked. This study analyzed the socioeconomic status of 248 fishing households who are dependent on hilsa shad (Tenualosa ilisha) sanctuaries in southern Bangladesh. Also, the fishers' perceptions were investigated to assess the status of ecological restoration, level of participation in the hilsa sanctuary management, their livelihoods constraints, and coping strategies during crises. Based on the fishers' perceptions and fishery catch data of the government, it appears that the establishment of the hilsa sanctuary in the Bangladesh waters helped to restore the hilsa fishery and also enhanced the fishers' income. However, a large section of hilsa fishers were found to be poor in terms of socioeconomic capital such as monthly income, housing conditions, and assets ownership. Particularly, these households suffer seasonal food insecurity during the banned period of fishing in the sanctuaries. The government's compensation scheme is a good example of payment of ecosystem services in an open water fishery; however, this scheme does not include all the affected fishers. Food and income insecurity during ban period often force fishers to use illegal fishing as a livelihood strategy that undermines the success of sanctuaries as an ecological restoration strategy. The findings reflected that sanctuaries and other similar management strategies have social impacts on stakeholders and human societies, and these social impacts can have surprising feedbacks that influence management success. Thus, the success of ecological restoration relies on understanding the human dimensions of the system and that ecological and social restoration must go together. To address this goal, we call for developing fisheries policy that will facilitate engagement of resource users and other local stakeholders in sanctuary comanagement, which will ultimately strengthen fishers' livelihoods and sustain the benefit from ecological restoration.
\end{abstract}

Keywords: hilsa shad sanctuaries; livelihood sustainability; comanagement; ecological restoration

\section{Introduction}

Ecological restoration is the process of helping the recovery of an ecosystem that has been degraded, damaged, or destroyed [1]. Because of its instrumental role in reestablishing habitats and improving the functioning of ecosystems, ecological restoration became an important strategy for biodiversity conservation [2]. For ecological restoration, the establishment of different types of spatially explicit restriction measures in marine areas (commonly termed as marine protected areas 
(MPAs), sanctuaries, parks, harvest refugia, marine reserves, etc.) is one of the most important and popular strategies [3,4]. MPAs are well known for their biological roles including rehabilitation of damaged habitats, conservation of biodiversity, enhancement of ecosystem services, spillover of fish into local fisheries, mitigation of climatic and environmental threats, insurance against environmental or management uncertainty, and sites for basic scientific inquiry. Besides biological roles, the majority of MPAs are also hypothesized to play social roles such as restoring subsistence fisheries, generating economic opportunities, and empowering coastal communities, as well as promoting tourism and aesthetic benefits [4-7]. Given that restoration is often costly and requires substantial support from the government and the communities, understanding the social and ecological contexts of coastal recovery is essential to ensure their sustainability.

However, the social aspects of restoration often receive lesser priority, or are neglected in the efforts of natural resources management. Though the MPAs are designed, implemented, and managed through complex socioeconomic and political processes, policymakers have been somewhat inattentive to human dimensions. These include social, economic, and institutional considerations; these can profoundly affect the outcome of MPAs implementation [8]. Where social impacts of MPAs have been evaluated, these provide only limited understanding, because evaluations tend to focus on one or very few outcomes and thus lack a detailed account of the social implications of MPAs [6,9-11]. Thus, the social impacts of no-take sanctuaries or MPAs or marine reserve remain unresolved [12]. The understanding of the social impacts is important because MPAs might have negative consequences for the livelihood assets and well-being of fishers (i.e., displacement and loss of income), which could ultimately lead to unintended ecological consequences through social noncompliance $[7,10,13]$. For example, in frustration of losing fishing rights and subsequent vulnerable situations, people might resort to poaching within protected areas [13]. Fishers affected by MPAs might be less resilient to global changes since their fishing rights become constrained. For instance, they have less "action space" due to different policy and regulatory bindings of the protected areas [13]. Thus, if the social dimensions are ignored or insufficiently addressed, MPAs may fail as effective management and restoration strategies $[7,14]$.

The social dimensions of MPAs such as acceptance of conservation rules, social mechanisms of conflict resolution, and cooperation of regulatory compliances, social justice, participation in management, sharing of economic benefits, etc. are therefore crucial for its success. Hence, any ecological restoration project including MPAs is not only a technical task of restoring an ecosystem but also a sociopolitical enterprise, i.e., it has an important human element, with strong social and political connotations $[15,16]$. The argument over such interest is that fishers have a wealth of indigenous knowledge and experience that can be integrated into the decision-making process to help improve the performance of sanctuaries [17]. If fishers have an unfavorable view towards sanctuaries, they are likely to be unsupportive and may violate the regulations, thus reducing the effectiveness of sanctuaries. For developing a management strategy, or to revise existing management strategies of MPAs, a necessary first step is assessing the information about the socioeconomic status of dependent fishing communities [18]. When social considerations are incorporated, conservation planning becomes more realistic and inclusive, makes conservation goals more likely to be achieved and to be more sustainable, thus eventually enhancing the appropriateness and effectiveness of implementation initiatives [19]. Similarly, should social considerations of hilsa sanctuaries be taken into account, it will be helpful for enhancing the effectiveness of the sanctuaries through community acceptance and more compliance with the rules.

Hilsa shad (Tenualosa ilisha) constituted the single largest fishery in Bangladesh [20]. The fishery contributes about $11 \%$ of the total fisheries production, provides employment to 0.5 million people directly and another 2 million people indirectly, and adds about $1 \%$ contribution to GDP [21,22]. To protect the fishery from the growing overfishing trend, the government of Bangladesh (GoB) has declared five sanctuaries in the Meghna-Padma Rivers and other associated tributaries with a total area covering $350 \mathrm{~km}^{2}$. The Department of Fisheries (DoF) in cooperation with law enforcement 
agencies and local government administration initiated a countrywide ban for eight months from November to June every year on fishing of catching, carrying and selling of jatka (juvenile hilsa less than $25 \mathrm{~cm}$ in size). Another restriction is placed on the catching of brood (mature and about to spawn) hilsa for 22 days during the peak breeding season in October [22,23]. The government has initiated a Payment for Ecosystem Services (PES) program for fishing communities (covering 187,000 households) with 40 kilograms of rice per household per month and supporting alternative income-generating activities such as cash, rickshaw/van and sewing machine, to compensate for loss of earnings due to fishing restrictions [22]. The establishment of sanctuaries is found successful to revive hilsa fishery, which is reflected in increased hilsa production from 199,000metric ton (MT) in 2003 to 500,000 MT in 2017. However, it places a strain on the livelihoods of fishers as the incentive supports are inadequate to compensate fishers and not included all fishers in this scheme [24]. This situation is particularly alarming since unsustainable fishing practices result in increased competition, social noncompliance and conflicts during harvest, which could undermine management effectiveness [20].

Different studies suggested that involving fisher-folks in decision-making, and sharing of power and responsibilities between the government and the communities through fishery comanagement would enhance the effectiveness of management initiatives [25]. As such, comanagement is often seen as an effective global strategy to halt the degradation of fisheries resources, avoid conflicts from resource scarcity, improve equity in resources distribution, and improve the effectiveness and appropriateness of fishery management initiatives including ecological restoration [26,27]. The success of comanagement could be examined and evaluated using socioeconomic indicators of sanctuary-dependent communities such as economic, attitudinal, and behavioral aspects of the communities, the condition of the resource itself, as well as aspects of wider ecology [28]. Thus, a baseline of knowledge on the socioeconomic status of sanctuary-dependent communities is important for the measurement of success of a sanctuary.

Though the conservation of hilsa fisheries received much more attention by the policymakers, livelihood sustenance of the fisher communities has been overlooked over the years. Only recently, a few studies were conducted on the social acceptance of hilsa sanctuaries [20]. Still, a detailed description of socioeconomic profiling of small-scale fishers' dependent on hilsa sanctuaries is missing. A viable, healthy fishing community is a prerequisite for the preservation of healthy fishery ecosystems [25]. Therefore, ensuring health and wellbeing of fisher communities is a necessity for sustainable management of any fishery. The objectives of the present study aimed at providing empirical evidence to strengthen further the arguments that socioeconomic conditions regulate the behavior of resource-dependent communities that affect the success of the establishment of sanctuaries or MPA. The outcomes of the investigation would help policymakers and managers to be better informed for more balanced consideration of social dimensions in future policy making [28]. Using the sustainable livelihood approach as the analytical framework, the present research would analyze the socioeconomic conditions of hilsa fishing communities adjacent to river sanctuaries. This study would assess to what extent the establishment of sanctuaries did affect social conditions of the fishing communities and how these social impacts influence the management success of ecological restoration.

\section{Theoretical Framework}

For an analytical framework, this study draws on the theories of livelihoods and marine protected areas (MPAs). The sustainable livelihood literature, such as [29-32], broadly defined livelihood in terms of requirements for, and processes of, gaining a living, satisfying needs and improving standards of living, which provide a lens for our analysis. Ellis [31] defines a livelihood as comprising of "the assets (natural, physical, human, financial and social capital), the activities, and the access to these (mediated by institutions and social relations) that together determine the living gained by the individual or household". The SLA framework contains several components: (a) capitals broadly categorized into five different types, which are owned or accessed by people: human capital, financial capital, physical capital, natural capital and social capital; (b) the risk factors that surround the livelihoods 
are summarized as the "vulnerability context", where vulnerability is defined as "proneness to a sudden, catastrophic, fall in the level of a variable, usually access to enough food for survival" [33]; (c) the structures associated with formal organization, e.g., government (national and local), NGOs, laws and rights, social relations and participation, are summarized as the "transforming structures and processes"; (d) "livelihood strategies" are the range and combination of activities and choices that people undertake or make to achieve livelihood outcomes; and (e) people's livelihood strategies, conducted within these contexts, result in "livelihood outcomes" as higher or lower material well-being, reduced or increased vulnerability, poverty reduction, etc. [34].

Livelihoods are sustainable when people (a) are resilient in the face of external shocks and stress; (b) are not dependent upon external support (or if they depend, this support should itself be economically and institutionally sustainable); (c) maintain the long-term productivity of natural resources; and (d) do not undermine the livelihoods of, or compromise the livelihood options open to others [35]. There are several justifications for employing the sustainable livelihood approach as an analytical lens for the present study. SLA recognizes (i) the multiple and diverse character of livelihoods, (ii) the prevalence of institutionalized barriers to improve livelihoods, (iii) the social and economic character of livelihood strategies, (iv) the principle factors implicated in rising or diminishing vulnerability, and (v) the micro-macro (or macro-micro) links that connect livelihoods to policies [34]. The application of the SLA in fisheries has certain merits as illustrated by [36]. They suggest that the "SLA has emphasized the cross-sectorial diversity of household livelihood strategies among fisher folk, the pervasive influence of formal and informal institutions on livelihoods and resource management, the social and economic heterogeneity of households engaged in fishing and the multi-dimensional nature of poverty" (p. 764). In the context of this framework, a marine-protected area can be seen as a sociopolitical institution that is comprised of a series of laws, policies, and processes that are enacted by various levels of government (as well as private sector and civil society actors) through applied governance and management [7].

\section{Contexts and Methods}

The study was conducted with hilsa fishing communities living adjacent to hilsa shad sanctuaries in the Meghna River basin during the period from August 2015 to August 2017. The communities living along the Meghna River system differ from each other in terms of location, social and cultural norms and practices, and the role of women in income-generating activities. Hence, to get an accurate representation of fisher communities across working areas, the respondents were selected from six different Upazilas (subdistrict) namely Taltoli (Barguna district), Char Fassion and Daulatkhan (Bhola district), Haimchar (Chandpur district), Kalapara (Patuakhali district), and Hijla(Barisal district) (Figure 1). These sub-districts are situated along the Meghna River except Kalapara and Taltoli, which are located on the site of Andharmanik River on the central coast of Bangladesh.

For collecting baseline data of a longitudinal study, the Upazila (sub-district) Fisheries Officer (UFO) was approached to identify at least four villages where hilsa fishing is a dominant economic activity. Then the local community leaders were contacted to prepare a list of hilsa fisher households in their villages. In this study 350 households were approached for the survey, but 248 households were agreed to participate in this study. The households were selected through opportunity sampling and based on households' interest to participate in the study. Household surveys were conducted using a semistructured questionnaire. The questionnaire was pretested in the field and was adjusted accordingly. This study examined a number of socioeconomic indicators $[37,38]$ that were hypothesized to reflect their livelihood activities, economic conditions, and food security of small-scale fishing communities that are dependent on hilsa fisheries. The socioeconomic indicators involved material style of life (assets ownership), monthly income, and expenditure per household member; ownership of expensive assets, age; year of education; household occupational multiplicity; and whether fishing was the household's primary occupation, the extent of hunger, and dependency on hilsa sanctuary for the yearly income. In this regard, we examined the type of walls, roof, and floor in respondents' homes 
and inquired whether they had a radio/television and access to drinking water and a sanitation facility. The occupational multiplicity of households was investigated by asking the fishers if they do any other job particularly during the fishing ban period. Data were entered in Microsoft Excel and analyzed in IBM SPSS version 22. A number of qualitative information were elicited by asking questions on coping strategies during closures and other crises, respondents' involvement in management, perception regarding changes in catch per unit efforts, etc. A content analysis was employed for the qualitative data analysis [32]. A content analysis is a research tool that interprets and codes different communicated materials (e.g., documents, articles, books, voices, interviews, and images) through classification, tabulation, and evaluation of its key themes to ascertain its meaning and probable effect. This scientific tool is particularly useful as it provides new insights, thus enhancing a researcher's understanding of particular phenomena as well as informing practical measures [39]. In the present study, textual materials were coded in manageable categories of different variables [40].

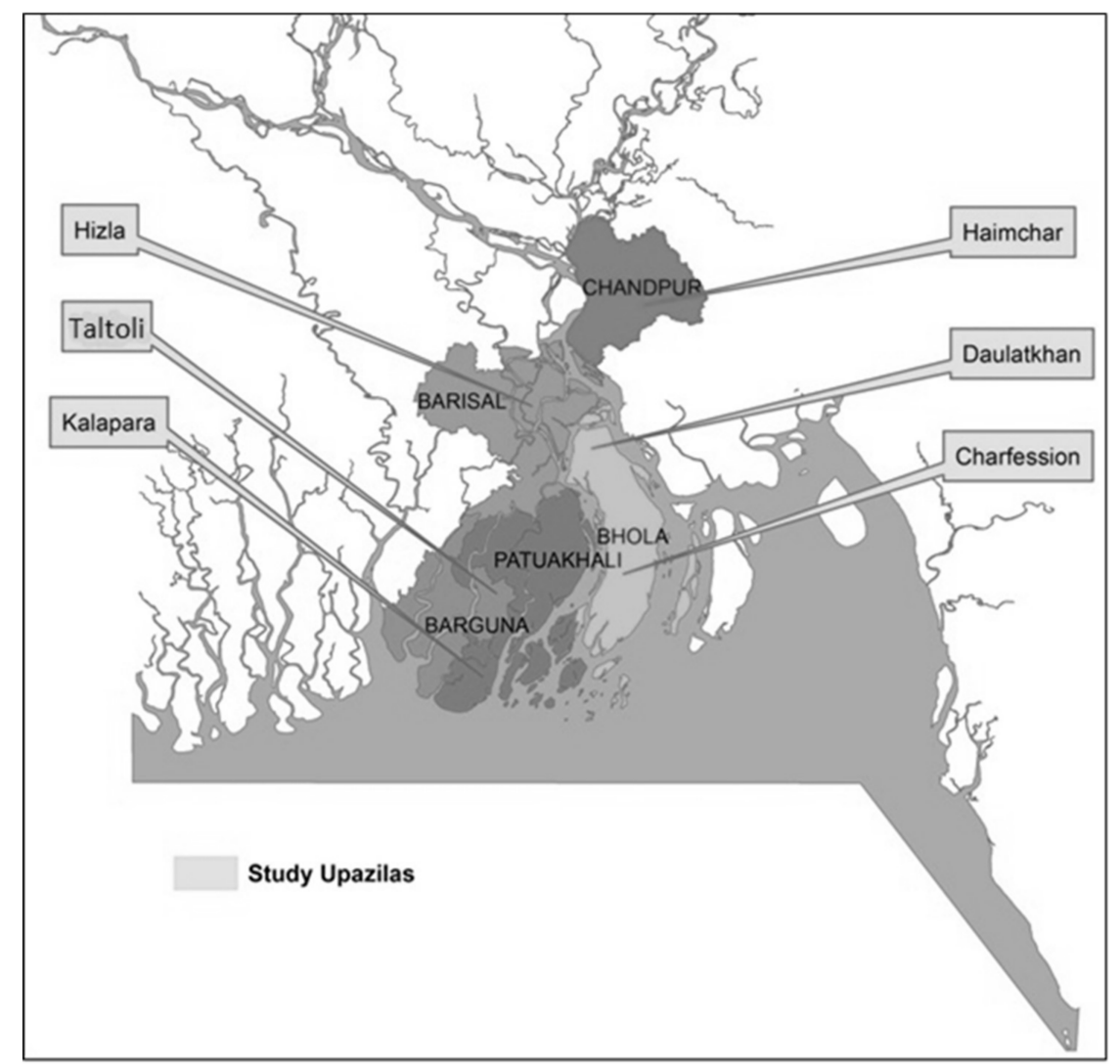

Figure 1. Map showing the study areas in river system of Bangladesh.

\section{Results}

\subsection{Socioeconomic Profileof Hilsa Fishers of the Sanctuaries}

The livelihood capitals were studied to get a reflection of the living conditions of the respondents and their capacity to earn a living (Table 1). About one-third of household heads (31.9\%) were at the age of 26 to 30 years old, nearly $25 \%$ between $31-35$ years, and another $25 \%$ were above 36 years. Only $17.7 \%$ of household heads were below 25 years. The average family size of the fisher households was 5.3 persons whereas the national average of Bangladesh is 4.4 (National average data collected from Bangladesh Bureau of Statistics [41]). About 61.7\% households had five or less than five, and the rest $(38.8 \%)$ had family member more than five people. More than $90 \%$ of fishers had either no schooling $(40.3 \%)$ or primary schooling only $(52.4 \%)$, whereas the national average rate of illiteracy is $35.34 \%$. Among the fishers, only $6.8 \%$ had completed eight years of schooling. For the majority 
of the households (53.2\%), the monthly income was between BDT 5000-10,000 (USD \$62.5-125), whereas the national average income per household per month is BDT 11479 (USD 144); $23.4 \%$ of households' income was between BDT 10,000-20,000 (USD \$125-250) and 11\% of households reported to earn >BDT 20,000 (USD \$250) monthly. However, 19\% of households reported their earning as less than BDT 5000 (USD \$62.5) per month. About half of the fisher households had at least one occupant with employment that is involved in fishing or other activities. About $37 \%$ of household heads reported to work $26-30$ days per month, $16.9 \%$ work for $21-25$ days per month, $26.2 \%$ work for 16-20 days per month, and only $19.8 \%$ work less than 15 days per month. About $88 \%$ of the yearly income of the households comes from fishing occupation conducted in the hilsa sanctuaries.

Use of destructive gear is widespread as about $93 \%$ of the respondents are reported to use monofilament gill net (locally known as "current jal") for hilsa fishing (Table 1).

Table 1. Socioeconomic and demographics condition of the studied fishers $(n=248)$ in the hilsa sanctuary areas of Bangladesh.

\begin{tabular}{|c|c|c|}
\hline Socioeconomic and Demographic Characteristics & Frequency & Percentage $(\%)$ \\
\hline \multicolumn{3}{|l|}{ Age (years) } \\
\hline$<25$ & 44 & 17.7 \\
\hline $26-30$ & 79 & 31.9 \\
\hline $31-35$ & 63 & 25.4 \\
\hline$>36$ & 62 & 25.0 \\
\hline \multicolumn{3}{|l|}{ Educational status } \\
\hline No education (illiterate and can sign only) & 100 & 40.3 \\
\hline Five years of schooling & 130 & 52.4 \\
\hline Eight years of schooling & 17 & 6.8 \\
\hline Ten years of schooling & 1 & 0.4 \\
\hline \multicolumn{3}{|l|}{ Housing conditions $(\mathrm{n}=248)$} \\
\hline \multicolumn{3}{|l|}{ Wall materials } \\
\hline Cane/palm/trunks & 8 & 3.2 \\
\hline Corrugated tin & 235 & 94.8 \\
\hline Cement \& bricks & 1 & 0.4 \\
\hline Wood planks \& shingles & 3 & 1.2 \\
\hline Others & 3 & 1.2 \\
\hline \multicolumn{3}{|l|}{ Roofing materials } \\
\hline Thatch palm leaf & 11 & 4.4 \\
\hline Bamboo with mud & 1 & 0.4 \\
\hline Hardboard/polythene & 1 & 0.4 \\
\hline Corrugated tin & 230 & 92.7 \\
\hline Roofing shingles & 1 & 0.4 \\
\hline \multicolumn{3}{|l|}{ Flooring materials } \\
\hline Earth/sand & 236 & 95.2 \\
\hline Wood planks & 7 & 2.8 \\
\hline Palm/bamboo & 1 & 0.4 \\
\hline \multicolumn{3}{|l|}{ Monthly income in Bangladeshi Taka (BDT) } \\
\hline$\leq 5000$ & 47 & 19.0 \\
\hline $5000-10,000$ & 132 & 53.2 \\
\hline $10,000-20,000$ & 58 & 23.4 \\
\hline$\geq 20,000$ & 11 & 4.4 \\
\hline \multicolumn{3}{|l|}{ Working days per month } \\
\hline$\leq 15$ & 49 & 19.8 \\
\hline $16-20$ & 65 & 26.2 \\
\hline $21-25$ & 42 & 16.9 \\
\hline $26-30$ & 92 & 37.1 \\
\hline Use of monofilament gillnet (current jal) & & 93 \\
\hline Yearly income from hilsa fishing in the sanctuary & - & 88 \\
\hline
\end{tabular}

Most of the households ( $81.1 \%)$ had their house with two to four rooms. Only one respondent household had seven rooms in their house. However, $9.67 \%$ of these households' houses were only 
single-roomed. Different building materials were used in making the houses, 95.2\% had an earthen floor. According to the national survey, $90.8 \%$ of a roof and $48 \%$ of the walls of the rural households are made of corrugated tin; for fisher households, $92.6 \%$ of the roof and $94.7 \%$ of the walls are made of tin (Table 1). Only 16\% of the households have access to electricity whereas the national average rate is $63.6 \%$. Another 53\% fishing households use solar panel. Only 6\% households have television, $84 \%$ have mobile phones, and $1 \%$ has a refrigerator. Seventy-six percent of the respondent households have a sanitary toilet, and $83 \%$ have access to safe drinking water. Among these 248 fisher households, $71 \%$ of them have their own fishing nets, $38 \%$ of them have nonmotorized country boats, and $27 \%$ of them have a boat with motor power (Figure 2).

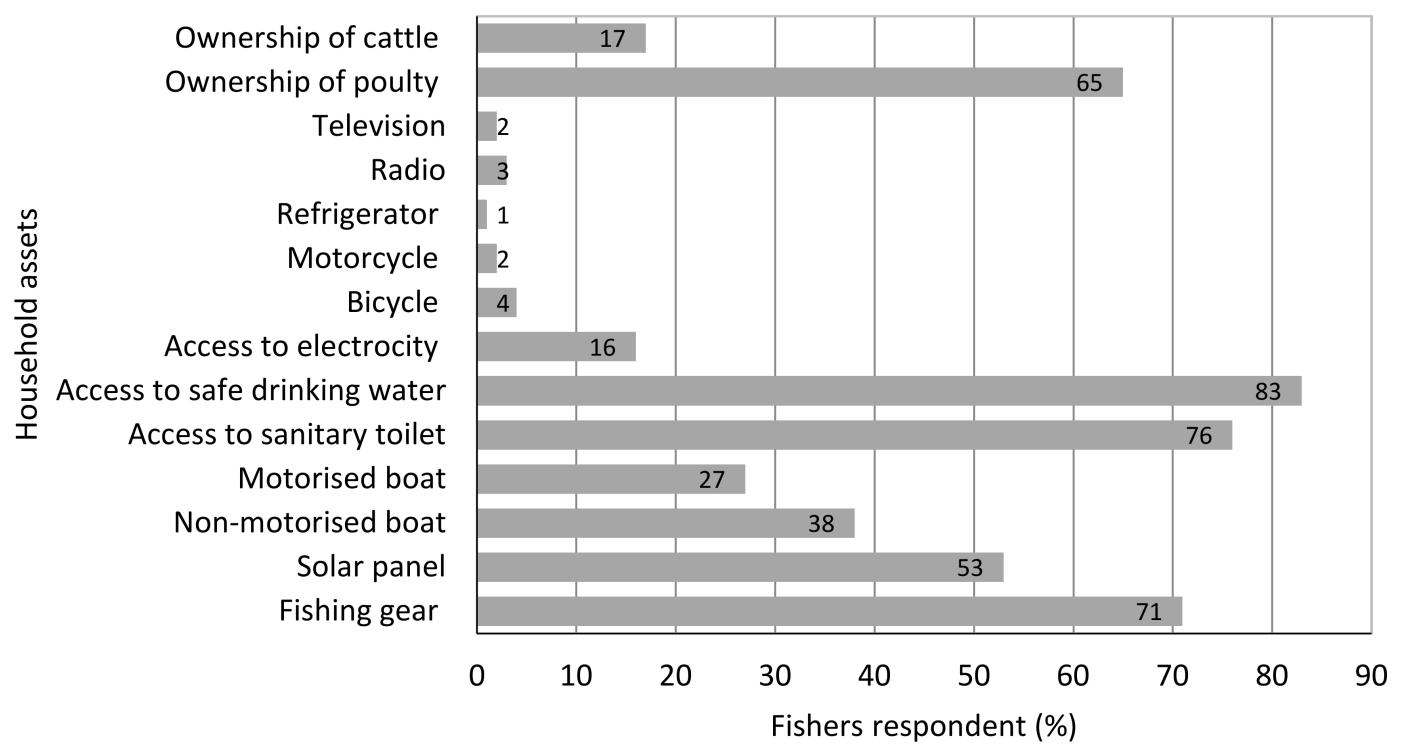

Figure 2. Households' ownership of assets.

The majority of the fishing households use straw or dried leaves (93.1\%) and wood (82.4\%) as the cooking fuel. Some households also used dried animal dung (9\%) and biogas (0.5\%) as cooking fuel. Among all 248 households, $65 \%$ have poultry birds, $17.0 \%$ own cattle and $22 \%$ own at least one fishpond at their backyard with subsistence level of farmed fish.

\subsection{Status of Food Security and Hunger Rate}

Household expenditure on food ranged from BDT 1000 to 10,000 (USD \$12.5 to \$125), and the most regular monthly expenditure was BDT 3000 to 4000 (USD \$37.5 to \$50), whereas the national consumption expenditure per household per month is BDT 11,003 (USD \$137.5). The fisher households suffer food insecurity and occasional hunger. A few households suffer from severe hunger (1\%), about $11 \%$ of the households suffered from moderate hunger, and the majority households $(88 \%)$ have occasional or no hunger at all in their households (Table 3). The data also passed the validity test by the Spearman correlation test. Household hunger state was significantly $(p=0.01)$ associated with monthly household income (Table 2). The majority of the households adopted different strategies to cope with a shortage of food, $71 \%$ of them borrowed food from their neighbors, 51\% took loans, and $31 \%$ ate fewer items of food or poor quality food. However, only $1 \%$ of participating households reported to take extreme measures like stop schooling of the children or sale or keep mortgage of assets. The ANOVA analysis suggests there is no statistically significant relationship among household income per month and coping strategies with food unavailability in the households. 
Table 2. Household hunger status by monthly income among the fishers $(n=248)$ in the hilsa sanctuary areas of Bangladesh.

\begin{tabular}{cccc}
\hline $\begin{array}{c}\text { Household Hunger } \\
\text { Status }\end{array}$ & $\begin{array}{c}\text { House Hold Income Bangladeshi } \\
\text { Taka (BDT) per Month }\end{array}$ & $\begin{array}{c}\text { Total Fisher } \\
\text { Respondents (\%) }\end{array}$ \\
\hline Little or no hunger & $\leq 8000$ BDT & $\geq 8001$ BDT & \\
Moderate hunger & 104 & $114(p=0.011)$ & 87.90 \\
Severe hunger & 21 & 6 & 10.89 \\
\hline
\end{tabular}

\subsection{Access to Government Support Scheme and Other Supports}

Besides the establishment of the sanctuaries, there are different processes, policies and institutions that affect hilsa fishers' livelihoods. The households received different supports mainly from the government. More than half (52\%) of the respondents do not have "jele card" (fishermen identification card) which is a pre-condition for getting incentives from the government during the ban period. The local government unit, Union Parishad, is responsible for enlisting genuine fishers for the jele card. A section of fishers complained that the process of enlistment is not fair, due to the existence of nepotism and corruption. Only $35.2 \%$ of the respondents said they receive government support (rice grain) during the ban period. Among the people who had received government support during the ban period, only $61 \%$ reported they received it regularly, and the rest said it is very uncertain to receive support in time during the fishing closures. Besides the government's incentive program, some households had received other supports. For example, almost $33 \%$ of the studied population received cash for education programs; very few (3.2\%) reported to receive old age allowance. A fairly large percentage $(59.1 \%)$ received supports from the NGOs. Most of these NGOs ran microcredit programs, few other NGOs ran training program to train the locals on different sustainable livelihood options, and provided them with assets, for instance, sewing machine, fish fingerlings, etc.

\subsection{Key Constraints to Fishers' Livelihoods}

The fishers reported different shocks and stress to which they are vulnerable. When questioned about what constraints they face, the fishers reported different constraints in their livelihoods (Table 3). "Too many fishers chasing too few fish" was a common response from the respondent fishers indicating the increased number of fishers that lead to overfishing, particularly by using illegal fishing gears. However, some fishers indicated bumper catch of hilsa shad in short duration period that provided them a good income. Some of these constraints came after the establishment of sanctuaries in their fishing areas. The most frequent response from fishers was loss of income as a direct consequence of the ban period in the sanctuary. The different responses included, "Fishing is the only job I learned from my forefather, so I am not able to earn by doing other occupation", "During ban season I have no fishing, so no income." To compensate the loss of fishing income, the government provided rice incentives to the affected households. The amount of $40 \mathrm{~kg}$ of rice per month for 4 months is insufficient as reported by the respondent fishers. They further reported that no cash incentives were received to meet other family expenses such as education and medical expenses. Apart from fishing skills, fishers usually do not have other occupational skills. Those who wish to seek an alternative occupation are usually not successful in earning a suitable income-generating activity. As one fisher said, "I feel uncomfortable to do another job that returns me less income than my fishing occupation." Thus, to continue their livelihoods, fishers took a loan from microcredit organizations, also from moneylenders and middlemen in the fish value chain. "It is a common practice for many fishing households to take microcredit from one NGO to repay to another NGO, thus they always remain indebted to microcredit", said another fisher. As such, the majority of the respondents reported indebtedness to NGOs. The fishers' villages are located along the bank of rivers, so fishers reported natural disasters, like flood and cyclones, as threats to their settlement. Further, many fishers reported that they 
live on government-owned khas land after they lost their homestead land due to riverbank erosion. Fishing equipment is the primary means of livelihood earnings for the majority of the respondents. However, fishers reported a loss of fishing gears due to extreme events. Confiscation of fishing gears is also done by law enforcement agencies when these gears are caught red-handed during illegal fishing in the sanctuaries (Table 3). Other examples of livelihood constraints are conflicts during fishing and limited access to health and education facilities in remote locations.

Table 3. Major constraints most commonly reported by the respondents (multiple responses).

\begin{tabular}{|c|c|c|}
\hline Major Constraint & Frequency (\%) & Examples of Specific Drivers \\
\hline $\begin{array}{l}\text { Poverty and lost income } \\
\text { during ban period }\end{array}$ & 81 & $\begin{array}{l}\text { Majority of the fishers are illiterate, limited alternative skills } \\
\text { Some people come to fishing as last resort activity } \\
\text { Establishment of different fishery closures in the sanctuary }\end{array}$ \\
\hline $\begin{array}{l}\text { Indebted to money lenders } \\
\text { and microcredit institutions }\end{array}$ & 76 & $\begin{array}{l}\text { Hilsa fishery is capital intensive activity } \\
\text { Most fishers cannot afford investment capital due to poverty } \\
\text { Patron-client relationship with money lender } \\
\text { Taking microcredit to cope with sudden shock }\end{array}$ \\
\hline $\begin{array}{l}\text { Limited opportunity of } \\
\text { alternative occupations }\end{array}$ & 76 & $\begin{array}{c}\text { Remoteness from the main economic hub region } \\
\text { Limited or no skills for alternative occupation } \\
\text { Fishers are not interested in less remunerative or "socially low" } \\
\text { menial occupation }\end{array}$ \\
\hline Exposure to climate events & 67 & $\begin{array}{c}\text { Fishers lost their dwelling and assets frequently by river bank erosion } \\
\text { The working area and living place also vulnerable to cyclones } \\
\text { Couldn't fishing during cyclones/storms } \\
\text { Loss of lives of human beings and livestock } \\
\text { Obstruction to carry out normal lifestyle due to water logging }\end{array}$ \\
\hline Seasonality in fish catch & 65 & $\begin{array}{c}\text { Overfishing } \\
\text { Increased number of fishers } \\
\text { Rampant use of illegal fishing gears }\end{array}$ \\
\hline $\begin{array}{l}\text { Limited access to basic } \\
\text { facilities (health, education, } \\
\text { drinking water) }\end{array}$ & 56 & $\begin{array}{l}\text { Fishers hold the lowest position of social hierarchy Ignorance about } \\
\text { basic rules of health and sanitation } \\
\text { Tendency of sending children to fishing rather than to schooling. }\end{array}$ \\
\hline Loss of fishing gears & 44 & $\begin{array}{l}\text { Cyclone or flood water wash away the gears } \\
\text { Conflicts among fishers also cause damage or loss of gear } \\
\text { Confiscation and damage of gears by law enforcing agencies }\end{array}$ \\
\hline Conflicts & 43 & $\begin{array}{c}\text { Do not get proper incentives from government. } \\
\text { Alleged harassment from governmental bodies } \\
\text { The corruption of a section administrative personnel } \\
\text { Conflicts among fishers for fishing space and incentive program }\end{array}$ \\
\hline
\end{tabular}

\subsection{Fisher's Response to Crisis in the Sanctuaries}

The majority of the fishers indicated the positive trend of catch per unit efforts after the establishment of the sanctuaries, though, in the initial stage and in recent years, the catch moderately increased, particularly in 2016 when fishers experienced bumper hilsa catch (Figure 3). The increased catch also resulted in enhancing the fisher's income (Figure 4). Though in the case of extremely poor fishers, the income increased moderately, while in other income groups, the increased income was higher. The majority of the fishers attributed these positive trends of hilsa catch and income to the establishment of sanctuaries that protected brood and juvenile hilsa. When the respondents were asked if they have any participation in the management of hilsa sanctuary, more than two-thirds answered negatively. Only a few respondents felt that they have some participation in the management initiatives of the sanctuaries (Figure 5). However, the majority of the fishers expressed their willingness to participate in the hilsa fisheries management in the sanctuaries (Figure 5). 


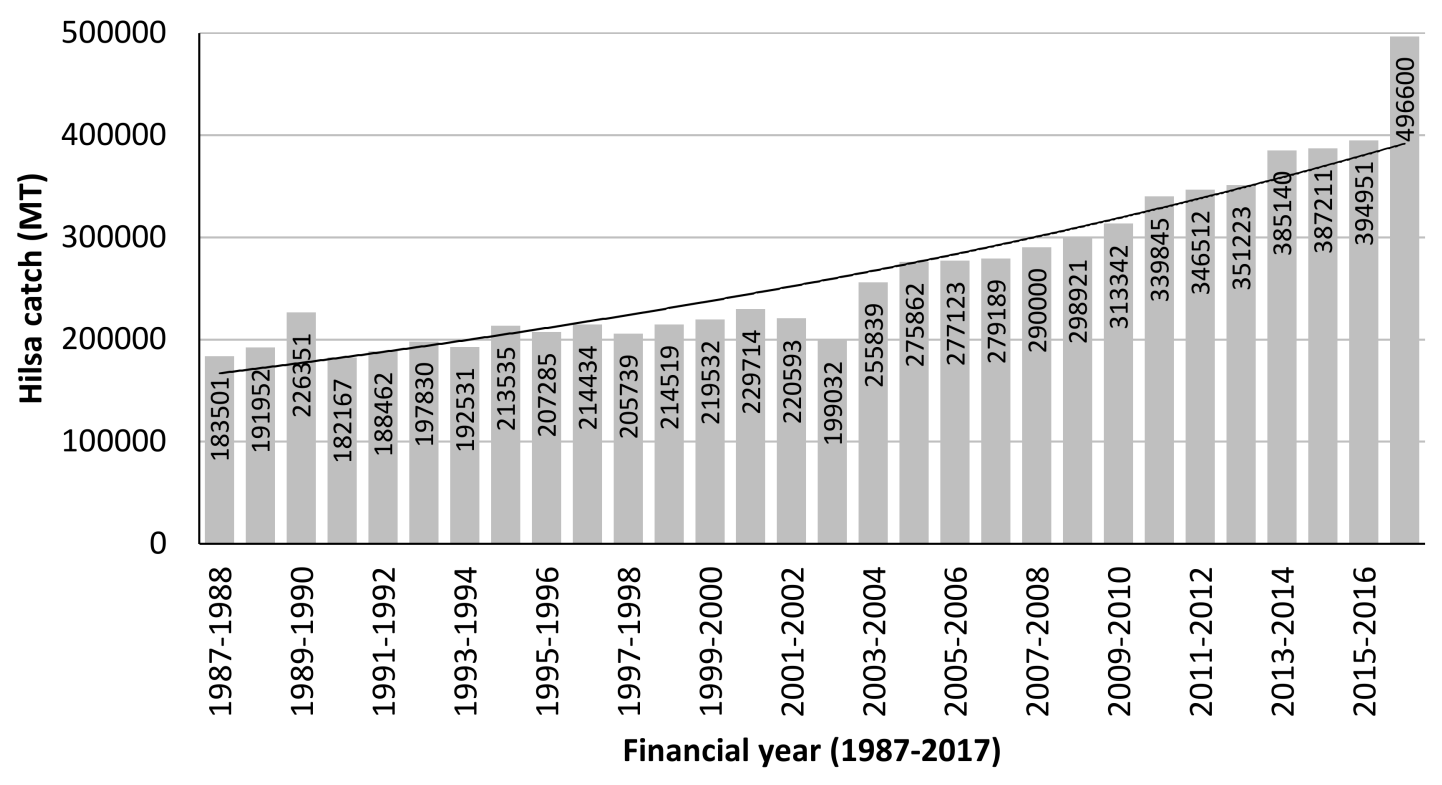

Figure 3. Increasing trend of hilsa production after hilsa management action plan introduced in 2003 [42].

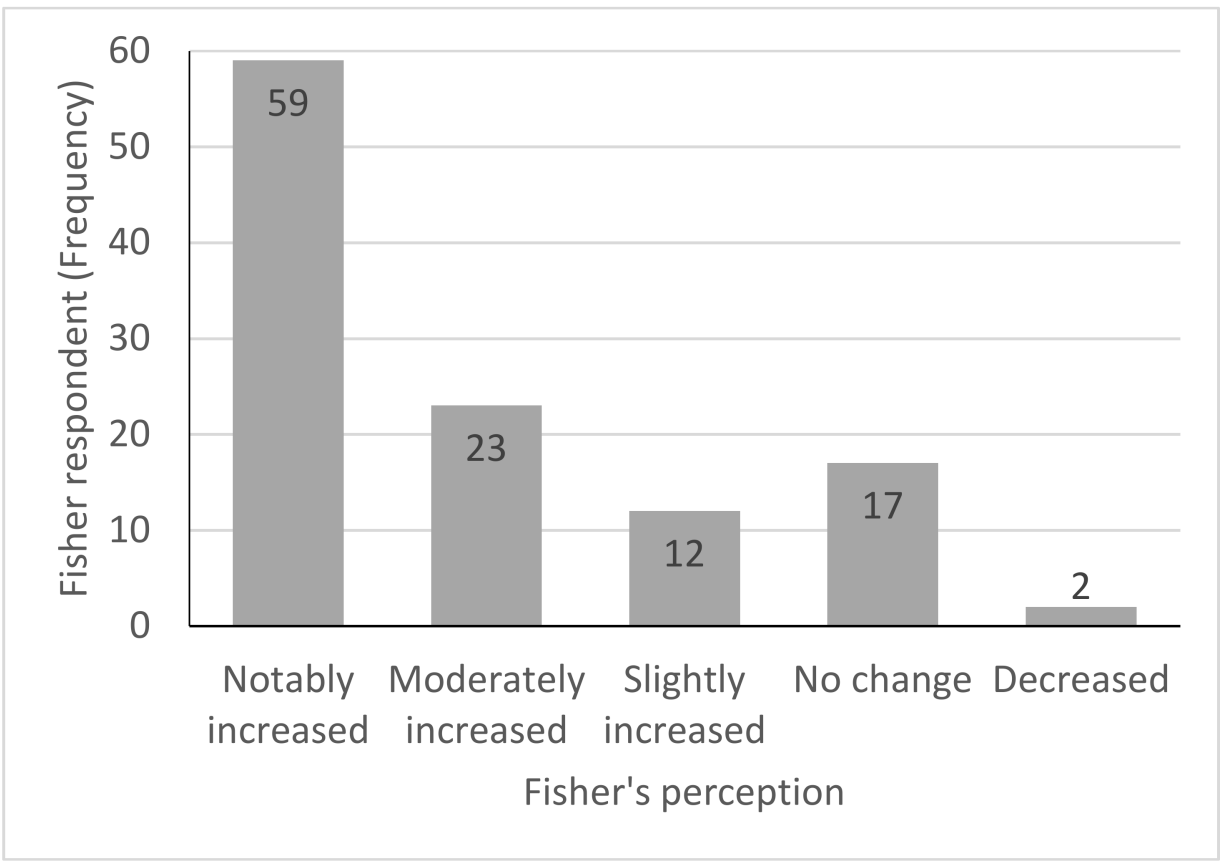

Figure 4. Fishers' perception regarding increase in fishery income compare to before and after sanctuary establishment in $2005(\mathrm{n}=113)$. 


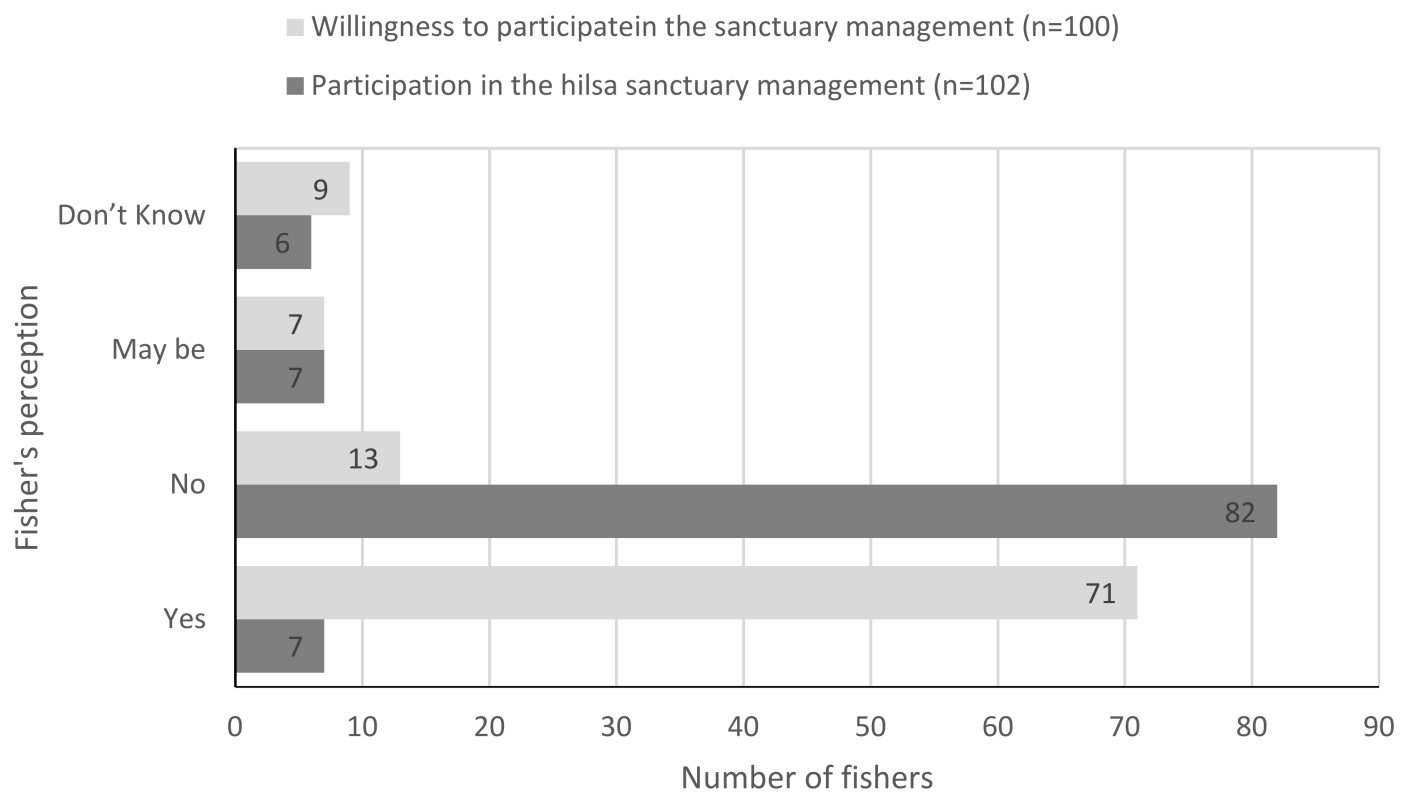

Figure 5. Fisher's perception regarding existing participation and their willingness to participate in the hilsa sanctuary's management.

\subsection{Fishers'Response to a Crisis in the Sanctuaries}

The hilsa fishers adopted different livelihood strategies to cope with crises they face. Responding to the question as to how they compensate for income loss during ban period, the fishers mostly reported negative approaches to coping strategies. To buy food, they draw from their own savings, taking loans from commission agents (fish traders) or boat owners, an interest-free loan from relatives, or a microcredit from NGOs. In case of failure in getting any loan, fishers reported to reduce the number of family meals per day. To cut expenses, particularly during their ban season, fishers take out their children from school and often put them into income-generating activities wherever possible. The fishers also take up strategies that put pressure on the fisheries resources. Illegal fishing during the banned period or using destructive fishing gears also are very common, as reported by the respondents. Particularly, more than $90 \%$ of the respondents reported having ownership and the use of a monofilament gillnet (current jal) during fishing in the sanctuaries (Table 1). In response to questions as to why they use the illegal monofilament gillnet, a major proportion of the fishers reported that they are poor, and need to earn livelihoods by any means, and that monofilament gillnets are cheaper and efficient in of catching of fish than other gears. Thus, they rely on a monofilament gillnet for subsistence living. However, a number of other factors were identified responsible for the widespread use of illegal gears and fishing during the ban period. They reported that current jal is easy to operate, costs less money to buy, and usually catches more fish than conventional gears. The fishing operation by current jal also requires less time and minimum manpower and also lasts for a longer period. During off-peak season, they use a current jal with the hope that as at least some fish can be caught. As the net is easy to operate, even child labor can handle the fishing operation. In most of the sites visited, it was found that it was difficult for most fishermen to adopt alternative legal fishing gears as the majority of the fishers are poor, dependent on moneylenders, and thus have limited capital to buy legal but expensive gears. As a consequence of noncompliance, fishers' face punishment from law enforcement agencies, which includes confiscation of fishing gears, fines, and imprisonment.

\section{Discussion}

As the single most important fishery of Bangladesh with social, economic and cultural value, the hilsa shad fishery management has attracted a high level of attention. To protect hilsa catches from 
declining, the Department of Fisheries adopted the Hilsa Fisheries Management Action Plan (HFMAP) in 2003. Following this plan, the government established five sanctuaries and implemented different strategies such as a total ban on catching jatka (juvenile species) and mother hilsa, the introduction of payment of ecosystem services as compensation for lost income, and raising awareness about hilsa conservation. The establishment of sanctuaries is considered a successful strategy for enhancement of natural capital of hilsa in the Bangladesh waters, although catch per unit effort (CPUE) data is lacking to assess the exact extent of recovery of hilsa stocks. Nevertheless, there are indications that the establishment of sanctuaries has helped ecological restoration and halted the decline of hilsa stock reflected in the higher catch statistic of overall hilsa production-both from the inland and marine waters of Bangladesh [22]. There are also widely held views among the fishers that establishment of hilsa sanctuaries also increased the abundance and biodiversity of other fish in the sanctuaries [20]. In recent years, it is reported in the newspapers and other popular media about 'bumper' production of hilsa in the Bangladesh waters and restoration of hilsa population in the rivers and water bodies where hilsa was heavily depleted. Bangladesh's success of ecological restoration of hilsa species provides a unique example for other countries facing similar problems for restoring their declining hilsa fisheries [43]. Thus, the importance of hilsa sanctuaries to ecosystem restoration in large-scale river fisheries are well-founded in Bangladesh. However, there are several challenges that affect the management effectiveness of the sanctuaries. Particularly, noncompliance of sanctuary regulations through illegal fishing with detrimental gears is a major concern. Hence, though sanctuaries are a common tool of fisheries and ecosystem management, their success relies on understanding the human dimensions of the system.

The establishment of sanctuaries led to some negative social consequences such as loss of income, unemployment, increased poverty, and decreased food security as reported in other studies in Southeast Asia [18]. The socioeconomic conditions of the fishers' households in the present study indicated that in comparison to the national average, fishers are often illiterate, have lower income, have less purchasing power, and live in conditions with limited basic facilities. The fishers are among the poorest people in Bangladesh. They have low levels of education and fishing skills cannot be readily convertible to other occupations. Thus, fishers are not well-placed to obtain an alternative occupation during seasonal closures [26,44]. The government's support of rice incentives was insufficient concerning a household's needs, and only half of the fishers' households were included in the beneficiary list. This situation created seasonal food insecurity for the poorer fishers households at least in part. Hence hilsa fishers are less resilient in the face of external shocks and stress, they have to rely on external support such as microcredit organization and they adopted some negative strategies that undermine their livelihoods. This situation indicated that livelihoods of hilsa fishers are not sustainable.

As a response, poorer fishers want to invest in cheaper, more efficient fishing gears (which are not illegal) to catch wide ranges of species to support their livelihoods. The fishers who use illegal gears are often caught by the law enforcement; their fishing assets are often confiscated, which furthers their financial instability. Since the imposition of fishery closures temporarily displaced from their only livelihood option, the poorer fishers suffered economic hardship during the ban period. For instance, fishers reported taking loans from the middleman, or from microcredit organizations which lead them to an endless debt cycle. These endless debt cycles influence them towards the tendency to practice illegal fishing methods in order to have a stable livelihood and repay their loans. As fishers are dependent on middlemen for their capital, middlemen often push fishers for illegal fishing with destructive gears for fulfilling their greed [18]. Another study [23] indicated that fishers continue fishing during the ban season to repay weekly loan installments to the microcredit institutions. These findings are broadly consistent with the situation of "poverty traps" in which the poor fishers are unable to mobilize the resources required to overcome either shocks or low-income situations and consequently engage in activities that may further reinforce their poverty $[45,46]$. 
Thus, fishers' socioeconomic conditions shape their behavior, which is reflected in the high level of noncompliance with fishery regulations [20]. The present study could not have established a direct link between socioeconomic conditions of the fishers and use of destructive gears and fishing during the ban period. However, different studies have indicated that those poor fishing households who experience less food security were more likely to use destructive fishing gear and were more noncompliant to fishery closures regulations $[47,48]$. This clearly indicated that sanctuaries and other similar management strategies have social impacts on stakeholders and human societies. These social impacts can have surprising feedback that influence management success. For instance, noncompliance of management regulations in the hilsa sanctuaries largely took place due to the poverty that resulted from the socioeconomic conditions of the fishing households. Therefore, the underlying social and economic reasons the fisher communities demonstrate noncompliance should be thoroughly understood and measures should be properly addressed for the restoration of these resources through the establishment of sanctuaries [2].

In order to maintain a viable fishery stock in any large or small open water ecosystem, healthy fisheries communities are essential and their proactive role is a requisite. Hence, for any fishery management, equal weight should be given for development of the communities that rely on it [25]. The livelihood analysis of fishing communities could help managers and policy makers to prioritize areas for intervention, which in turn will help maintain the natural capital that they rely on for livelihoods and income. The understanding of the scarce livelihood of the dependent population could prompt the managers to consult with communities before any conservation initiatives are taken and where fishing communities have a stake. Presently, fishers are rarely consulted with for any management decisions that might affect their livelihoods and occupations [18]. The success of ecological restoration at least partly depends on a better understanding of the socioeconomic drivers behind their behavior and practices. This could be better explained by a quote from IUCN [49], as "it is unacceptable to carry out conservation activities in areas of high or endemic poverty while turning a blind eye to the needs of the poor people who live there and depend on the same biological resources that are often those that we wish to conserve." Thus, the socioeconomic factors of any restoration project are just as critical to its success [50].

Hence, the collaboration and support of different stakeholders of the hilsa sanctuary are necessary for a long-term foundation for success of restoration [51], particularly when the protected area has communities depending on it [3]. So the interest of local communities in the effort must be enhanced, and their involvement should be solicited as much as possible [45]. A comanagement arrangement has appeared to work the best in this context [52], where both the local community and the local government share responsibility in the management of an ecosystem, with the anticipation of sharing the gains to be achieved [53]. At present, a top-down management approach is practiced for hilsa sanctuary, where different technical measures are taken (such as extending the period of fishery closure from 15 days to 22 days in October of each year), where fishers are not consulted before the measures are taken. The findings of the present study suggest for development of a comanagement arrangement in the hilsa sanctuaries with the hopes of empowering fishing communities to have a formal role in management measures. Access to comanagement funds would reduce the dependence on the middleman for gaining maximum economic benefits by the fishers. This positive benefit observed in a comanagement program, named the Management of Aquatic Ecosystem through Community Husbandry (MACH), implemented in the inland waters of Bangladesh, is still sustaining benefits to the poor and conserving aquatic biodiversity. In $\mathrm{MACH}$, fish catches increased 2-5 times, fish consumption increased by $45 \%$, and supplemental incomes of the fisher households increased by about $50 \%$ [54]. In the community-based fisheries management, access and use of waterbodies (jalmahals) were secured to organize fishing communities to a certain extent. Extensive evidence demonstrates that this approach has improved the productivity and biodiversity of these wetlands, while also benefiting the poor community, thus helping both ecological and social restoration. The establishment of comanagement in the river and inshore waters is largely consistent with the tradition, which could be replicated in the 
wider coastal zone management of Bangladesh. Development of policy and an appropriate regulatory system is required to establish comanagement authorities in the hilsa sanctuaries of Bangladesh.

\section{Conclusions}

The establishment of hilsa sanctuaries has been considered as a widely effective strategy for halting the decline of hilsa fishery in rivers, estuaries, and inshore waters of Bangladesh. Thus the sanctuary has also been contextualizing as an important tool for coastal fisheries restoration in Bangladesh. A number of strategies the government created has enabled condition for ecological restoration. The government has taken a management plan implemented through some technical measures, such as the declaration of five sanctuaries along the Padma-Meghna Rivers and their tributaries, temporary fishing bans on juvenile hilsa jatka and brood hilsa fishing, and the prohibition of use of destructive fishing gears like current jal (monofilament gillnet), behundi jal (set bag net) and similar gears. The government has also introduced payment for the ecosystem services program to the majority of the affected fishers with a 'jelecard' (Fishers ID Card), and also provided support in terms of rice and cash for alternative occupations. All these efforts helped to produce ecological restoration, which is reflected in the enhanced fisheries production, as well as the return of hilsa species in aquatic habitat from where it had declined over the last three decades. The surplus fisheries production helped to revitalize the local economy and led to an increase in fisher's income, but the majority of the fishers still remain poor in the material sense. During two ban periods, fishers suffer from food and income insecurity that negatively affect their well-being. To encourage social restoration, the government implementing different strategies that included distribution of compensation for affected fishers. The government support only covered about half of the fishing households, therefore noncompliance with sanctuary rules in the form of illegal fishing and use of illegal gears became a challenge for sustainability of the ecological restoration achieved. Thus, it is important to consider the social aspects of the sanctuary and strengthening the livelihood capital of all fishers as well as ensuring their participation in the process of restoration. Due to how socioeconomic conditions fundamentally regulate fisher's perception to conservation initiatives, this leads to their increased support for restoration project, such as the establishment of sanctuaries.

Currently, only $6 \%$ of the world's coastal areas are protected, while protected areas in the open oceans are very small. Aichi Biodiversity Targets \#11 of the Convention for Biological Diversity set a target of $10 \%$ of the coastal and marine areas to be designated as MPAs by 2020. Restoration is adopted as a strategy to achieve this target, which is supported by the Convention on Biological Diversity (article 8(f), [55]). Bangladesh is far behind in achieving the target. If Bangladesh wants to achieve the target by the stated period, more areas need to be declared as protected areas under restoration projects. As the poor are more dependent on natural resources, the establishment of more sanctuaries are likely to affect the poor communities in those areas. Thus the policymakers and managers need to well understand the interconnection between socioeconomic status and fisheries conservation needs. The establishment of comanagement arrangements could play an instrumental role in reducing poverty and enhancing the well-being of resource-poor fishing communities of the sanctuaries. In this arrangement, capacity building of local users through training should be included to create economic opportunities for the fishers. The engagement of resource users and other local stakeholders in sanctuary management will pave the way for sharing, learning, and innovation, which will ultimately strengthen fisher livelihoods.

Acknowledgments: This work was undertaken as part of the CGIAR Research Program on Fish Agri-Food Systems (FISH CRP). The authors acknowledge the financial support provided by USAID through the Enhanced Coastal Fisheries in Bangladesh (ECOFISH-Bangladesh) project, jointly implemented by the Department of Fisheries (DoF), Bangladesh and the WorldFish, Bangladesh and South Asia Office. The authors alone are responsible for the opinions expressed in this paper. We are grateful to Mohammad Mosarof Hossain, Department of Coastal and Marine Fisheries, Sylhet Agricultural Universityand two reviewers for their very useful comments for improving the manuscript. 
Author Contributions: M.M.I. analyzed data, compiled the draft and finally checked the manuscript. R.A. collected data from the field. M.N. developed the questionnaire B.K.B. supervised the research at the field level. M.A.W. read and revised the manuscript.

Conflicts of Interest: The authors declare no conflicts of interest. The founding sponsors had no role in the design of the study; in the collection, analyses, or interpretation of data; in the writing of the manuscript, and in the decision to publish the results.

\section{References}

1. SER. The SER International Primer on Ecological Restoration. Version 2. Society for Ecological Restoration International Science and Policy Working Group. 2004. Available online: www.ser.org/pdf/primer3.pdf (accessed on 12 January 2018).

2. Benayas, J.M.R.; Newton, A.C.; Diaz, A.; Bullock, J.M. Enhancement of biodiversity and ecosystem services by ecological restoration: A meta-analysis. Science 2009, 325, 1121-1124. [CrossRef] [PubMed]

3. Keenleyside, K.A.; Dudley, N.; Cairns, S.; Hall, C.M.; Stolton, S. Ecological Restoration for Protected Areas: Principles, Guidelines and Best Practices; IUCN: Gland, Switzerland, 2012.

4. Allison, G.W.; Lubchenco, J.; Carr, M.H. Marine reserves are necessary but not sufficient for marine conservation. Ecol. Appl. 1998, 8, 1431-1432. [CrossRef]

5. Lubchenco, J.; Palumbi, S.R.; Gaines, S.D.; Andelman, S. Plugging a hole in the ocean: The emerging science of marine reserves. Ecol. Appl. 2003, 13, 3-7. [CrossRef]

6. Christie, P.; McCay, B.J.; Miller, M.L.; Lowe, C.; White, A.T.; Stoffle, R.; Fluharty, D.L.; McManus, L.T.; Chuenpagdee, R.; Pomeroy, C.; et al. Toward developing a complete understanding. A social science research agenda for marine protected areas. Fisheries 2003, 28, 22-26.

7. Bennett, N.J.; Dearden, P. Why local people do not support conservation: Community perceptions of marine protected area livelihood impacts, governance and management in Thailand. Mar. Policy 2014, 44, 107-116. [CrossRef]

8. Charles, A.; Wilson, L. Human dimensions of marine protected areas. ICES J. Mar. Sci. 2008, 66, 6-15. [CrossRef]

9. Chen, C.; Lopez-Carr, D. The importance of place: Unraveling the vulnerability of fisherman livelihoods to the impact of marine protected areas. Appl. Geog. 2015, 59, 88-97. [CrossRef]

10. Mascia, M.B.; Claus, C.; Naidoo, R. Impacts of marine protected areas on fishing communities. Conserv. Biol. 2010, 24, 1424-1429. [CrossRef] [PubMed]

11. Crawford, B.R.; Siahainenia, A.; Rotinsulu, C.; Sukmara, A. Compliance and enforcement of community-based coastal resource management regulations in North Sulawesi, Indonesia. Coast Manag. 2004, 32, 39-50. [CrossRef]

12. Sale, P.F.; Cowen, R.K.; Danilowicz, B.S.; Jones, G.P.; Kritzer, J.P.; Lindeman, K.C.; Steneck, R.S. Critical science gaps impede use of no-take fishery reserves. Trends Ecol. Evol. 2005, 20, 74-80. [CrossRef] [PubMed]

13. Isaacs, M. Creating an action space: Small-scale fisheries policy reform in South Africa. In Poverty mosaics: Realities and Prospects in Small-Scale Fisheries; Jentoft, S., Eide, A., Eds.; Springer: Dordrecht, The Netherlands, 2011; pp. 359-382.

14. Oldekop, J.A.; Holmes, G.; Harris, W.E.; Evans, K.L. A global assessment of the social and conservation outcomes of protected areas. Conserv. Biol. 2016, 30, 133-141. [CrossRef] [PubMed]

15. Shackelford, N.; Hobbs, R.J.; Burgar, J.M.; Erickson, T.E.; Fontaine, J.B.; Laliberté, E.; Ramalho, C.E.; Perring, M.P.; Standish, R.J. Primed for change: Developing ecological restoration for the 21st century. Restor. Ecol. 2013, 21, 297-304. [CrossRef]

16. Chuenpagdee, R.; Pascual-Fernández, J.J.; Szeliánszky, E.; Alegret, J.L.; Fraga, J.; Jentoft, S. Marine protected areas: Re-thinking their inception. Mar. Policy 2013, 39, 234-240. [CrossRef]

17. Dalton, T.M. Beyond biogeography: A framework for involving the public in planning of US marine protected areas. Conser. Biol. 2005, 19, 1392-1401. [CrossRef]

18. Branch, G.M.; May, J.; Roberts, B.; Russell, E.; Clark, B.M. Case studies on the socio-economic characteristics and lifestyles of subsistence and informal fishers in South Africa. S. Afr. J. Mar. Sci. 2002, 24, 439-462. [CrossRef] 
19. Ban, N.C.; Mills, M.; Tam, J.; Hicks, C.C.; Klain, S.; Stoeckl, N.; Bottrill, M.C.; Levine, J.; Pressey, R.L.; Satterfield, T.; et al. A social-ecological approach to conservation planning: Embedding social considerations. Front. Ecol. Environ. 2013, 11, 194-202. [CrossRef]

20. Islam, M.M.; Islam, N.; Sunny, A.R.; Jentoft, S.; Ullah, M.H.; Sharifuzzaman, S.M. Fishers' perceptions of the performance of hilsa shad (Tenualosa ilisha) sanctuaries in Bangladesh. Ocean Coast. Manag. 2016, 130, 309-316. [CrossRef]

21. BOBLME. Management Advisory for the Bay of Bengal Hilsa Fishery. Regional Fisheries Management Advisory Committee, 2012. Available online: http:/ / www.boblme.org/documentRepository/BOBLME2012-Brochure-02.pdf (accessed on 15 December 2017).

22. Mohammed, E.Y.; Wahab, M.A. Direct Economic Incentives for Sustainable Fisheries Management: The Case of Hilsa Conservation in Bangladesh; International Institute for Environment and Development: London, UK, 2013.

23. Rahman, M.A.; Alam, M.A.; Flura, A.T.; Hasan, S.J.; Ahmed, K.K.U.; Zaher, M. Hilsa Fisheries Research and Management; Extension Manual No. 42; Bangladesh Fisheries Research Institute: Mymensingh, Bangladesh, 2011.

24. Islam, M.M.; Shamsuzzaman, M.M.; Sunny, A.R.; Islam, N. Understanding fishery conflicts in the hilsa sanctuaries of Bangladesh. In Inter-Sectoral Governance of Inland Fisheries; Song, A.M., Bower, S.D., Onyango, P., Cooke, S.J., Chunepagdee, R., Eds.; TBTI Publication Series; TBTI: St John's, NL, Canada, 2017.

25. Jentoft, S. The community: A missing link of fisheries management. Mar. Policy 2000, 24, 53-60. [CrossRef]

26. Pinkerton, E. Co-operative Management of Local Fisheries: New Directions for Improved Management and Community Development; University of British Columbia Press: Vancouver, BC, Canada, 1989.

27. Pomeroy, R.S.; Ahmed, M. Fisheries and Coastal Resources Co-management in Asia: Selected Results from a Regional Research Project; The WorldFish Center: Penang, Malaysia, 2006.

28. Wamukota, A.W.; Cinner, J.E.; McClanahan, T.R. Co-management of coral reef fisheries: A critical evaluation of the literature. Mar. Policy 2012, 36, 481-488. [CrossRef]

29. Chambers, R.; Conway, G. Sustainable Livelihoods: Practical Concepts for the 21st Century; IDS Discussion Paper 296; Institute for Development Studies: Brighton, UK, 1992.

30. DFID. Sustainable Livelihoods Guidance Sheets; Department for International Development: London, UK, 1999; pp. 1-8.

31. Ellis, F. Rural Livelihoods and Diversity in Developing Countries; Oxford University Press: Oxford, UK, 2000.

32. Allison, E.H.; Ellis, F. The livelihoods approach and management of small-scale fisheries. Mar. Policy 2001, 25, 377-388. [CrossRef]

33. Ellis, F. Human Vulnerability and Food Insecurity: Policy Implications; Theme Paper No.3; Forum for Food Security in Southern Africa; Overseas Development Institute: London, UK, 2003a.

34. Ellis, F. A Livelihoods Approach to Migration and Poverty Reduction; Department for International Development (DFID): Norwich, UK, 2003b.

35. Ashley, C.; Carney, D. Sustainable Livelihoods: Lessons from Early Experience; Department for International Development: London, UK, 1999.

36. Allison, E.H.; Horemans, B. Putting the principles of the Sustainable Livelihoods Approach into fisheries policy and practice. Mar. Policy 2006, 30, 757-766. [CrossRef]

37. Galobardes, B.; Shaw, M.; Lawlor, D.A.; Lynch, J.W. Indicators of socioeconomic position (part 1). J. Epidemiol. Community Health 2006, 60, 7-12. [CrossRef] [PubMed]

38. Cinner, J.E.; Daw, T.; McClanahan, T.R. Socioeconomic factors that affect artisanal fishers' readiness to exit a declining fishery. Conser. Biol. 2009, 23, 124-130. [CrossRef] [PubMed]

39. Krippendorf, K. Content Analysis: An Introduction to its Methodology Beverly Hills; Sage Publications: Thousand Oaks, CA, USA, 2004.

40. Spencer, L.; Ritchie, J.; O'Connor, W. Analysis: Practices, principles and processes. In Qualitative Research Practice: A Guide for Social Science Students and Researchers; Ritchie, J., Lewies, J., Eds.; Sage Publications Ltd.: London, UK, 2003; pp. 199-218.

41. Bangladesh Bureau of Statistics. 2012 Statistical Yearbook of Bangladesh; Statistics \& Informatics Division, Ministry of Planning, Government of the People's Republic of Bangladesh: Dhaka, Bangladesh, 2013.

42. Momi, M.A.; Department of Fisheries, Dhaka, Bangladesh. Personal communication, 2017.

43. Roy, P. Hilsa Coming Back to Rivers in Bangladesh. The Daily Star. Available online: https://www. thedailystar.net/frontpage/hilsa-coming-back-rivers-78177 (accessed on 15 December 2017). 
44. Islam, M.M. Living on the margin: The poverty-vulnerability nexus in the small-scale fisheries of Bangladesh. In Poverty Mosaics: Realities and Prospects in Small-Scale Fisheries; Jentoft, S., Eide, A., Eds.; Springer: Dordrecht, The Netherlands, 2011; pp. 71-95.

45. Cinner, J.E. Poverty and the use of destructive fishing gear near east African marine protected areas. Environ. Conserv. 2009, 36, 321-326. [CrossRef]

46. Van Brakel, M.L.; Nahiduzzaman, M.; Haque, A.B.M.; Mustafa, M.G.; Rahman, M.J.; Wahab, M.A. Reimagining large-scale open-water fisheries governance through adaptive comanagement in hilsa shad sanctuaries. Ecol. Soc. 2018, 23, 26. [CrossRef]

47. Peterson, A.M.; Stead, S.M. Rule breaking and livelihood options in marine protected areas. Environ. Conser. 2011, 38, 342-352. [CrossRef]

48. Islam, M.M.; Shamsuzzaman, M.M.; Mozumder, M.M.H.; Xiangmin, X.; Ming, Y.; Jewel, M.A.S. Exploitation and conservation of coastal and marine fisheries in Bangladesh: Do the fishery laws matter? Mar. Policy 2017, 76, 143-151. [CrossRef]

49. IUCN. Pro-Poor Conservation: Elements of IUCN's Conceptual Framework. Unpublished work. 2003.

50. Field, C.D. Rehabilitation of mangrove ecosystems: An overview. Mar. Pollut. Bull. 1998, 37, $383-392$. [CrossRef]

51. Egan, D.; Hjerpe, E.E.; Abrams, J. Human Dimensions of Ecological Restoration: Integrating Science, Nature, and Culture; Practice of Ecological Restoration Series; Island Press: Washington, DC, USA, 2011.

52. Katon, B.M.; Pomeroy, R.S.; Ring, M.; Garces, L.R. Mangrove rehabilitation and coastal resource management: A case study of Cogtong Bay, Philippines. Naga 1998, 21, 46-52.

53. Yap, H.T. The case for restoration of tropical coastal ecosystems. Ocean Coast. Manag. 2000, 43, 841-851. [CrossRef]

54. Halder, S.; Thompson, P. Restoring Wetlands through Improved Governance: Community Based Co-management in Bangladesh. In The Management of Aquatic Ecosystems through Community Husbandry $(M A C H)$ Experience; Winrock International, Bangladesh Center for Advance Studies, Center for Natural Resource Studies, CARITAS Bangladesh: Dhaka, Bangladesh, 2006.

55. Convention on Biological Diversity, The Ecosystem Approach; UNEP/CBD/COP/5/23 Decision V/6; UNEP: Nairobi, Kenya, 2000.

(C) 2018 by the authors. Licensee MDPI, Basel, Switzerland. This article is an open access article distributed under the terms and conditions of the Creative Commons Attribution (CC BY) license (http:/ / creativecommons.org/licenses/by/4.0/). 